\title{
DETERMINATION OF AFLATOXIN M1 LEVEL IN MILK AND SOME DAIRY PRODUCTS
}

\author{
Doaa Kh. Ibrahim*, Fatma I. El-Zamik, G-E.M. Mohamed and Howaida M.L. Abdl El-Basit
}

Agric. Microbiol. Dept., Fac. Agric., Zagazig Univ., Egypt, Postal Code (44511)

\begin{abstract}
The present study was carried out in the laboratory of agricultural microbiology Department, faculty of agriculture, Zagazig University, Egypt, in summer and winter seasons 2013 and 2014. In order to study the aflatoxin M1 (AFM1) contamination in milk, kareish cheese and yoghurt. AFMI was detected in raw milk in only 10 out of 12 samples (83.3\%) in each season. Winter season had higher AFMI concentration than summer season with the mean values of 311.8 and $207.0 \mathrm{ng} / \mathrm{l}$, respectively. AFMI was detected in all samples of kareish cheese (24 samples) in summer as well as in winter season. Winter season had higher AFMI concentration than summer season with average values of 651.36 and $527.40 \mathrm{ng} / \mathrm{kg}$, respectively. The present results observed that $83.33 \%$ of cheese sample examined exceeding the limits of EU (50 ng/kg), and (70.83\%) of cheese samples examined exceeding the limits of codex $(500 \mathrm{ng} / \mathrm{kg}$ ) in both summer and winter seasons. In yoghurt, the AFMI did not detect in 3 out of 12 samples of yoghurt tested. In summer season the positive samples ranged from 31.46 to $66.05 \mathrm{ng} / \mathrm{kg}$ with average of $39.13 \mathrm{ng} / \mathrm{kg}$. AFMI did not detect in only one out of 12 samples tested in winter season. Also, the positive samples ranged from 56.6 to $84.14 \mathrm{ng} / \mathrm{kg}$ with an average of $64.68 \mathrm{ng} / \mathrm{kg}$. Cheese had a higher concentration of AFMI than both raw milk and yoghurt. Also, yoghurt had the lowest concentration of AFMI comparing to raw milk and cheese. Heating treatments reduced the concentrations of AFMI in all raw milk samples tested. Boiling caused $26.71 \%$ degradion of AFMI, whereas pasteurization caused only $15.45 \%$ degredation. In yoghurt, two strains of probiotic bacteria (lactobacillus acidophilus and Bifidobacterium lactis) individually were gradually reduced the concentration of AFMI in contaminated milk with $25 \mathrm{ppt}$, as a function of time with complete elimination by the end of storage period (3 days) at refrigerator, while the cocktail of the two strains showed more ability for reducing AFMI. Both probiotic bacteria (L. acidophilus and B. lactis) showed more ability for reducing AFMI in contaminated milk with 50.0 ppt or 75 ppt.The most important reductions of AFMI concentration were 41.80 ppt (45.3\%), 2.6 ppt (69.90\%) and 7.12 ppt (92.8\%) which achieved by using the same concentration individually of each strain and in combination, respectively, in contaminated milk with 75ppt after two days. No AFMI was detected using combined strains after three days.
\end{abstract}

Key words: Aflatoxin M1, raw milk, milk product, heating, probiotic bacteria.

\section{INTRODUCTION}

The aflatoxins are a group of toxic and carcinogenic secondary metabolites produced by different Aspergillus species such as Aspergillus flavus, Aspergillus parasiticus, and Aspergillus nomius (Ito et al., 2001). Growth of a toxigenic aspergillus on a dairy products may result in contamination of that product with one or more of aflatoxin. It is possible for cheese to contain AFM1, if made from contaminated milk, and also B1 and other forms of aflatoxin if the cheese subsequently supports growth of a toxigenic aspergilli (Van Egmond and Dragacci, 2001). Some European Community and Codex Alimentarius prescribe that the maximum level

\footnotetext{
*Corresponding author: Tel. : +201007534542

E-mail address: zater2020@yahoo.com
} 
of AFM1 in liquid milk and dried or processed milk products should not exceed $50 \mathrm{ng} / \mathrm{kg}$ (Codex Alimentarius Commissions, 2001). Aflatoxins sometimes appeared in milk, cheese and other dairy products. Aflatoxin M1 (AFM1) is the hydroxylated metabolite of aflatoxin B1 (AFB1) under the influence of cytochrom p450 oxidase system found in the rumen microflora and the animals own cells and can be found in milk and subsequently in other dairy products when lactating animals are fed with contaminated feedstuffs (Van Egmond et al., 2007; Motawee et al., 2009; Dashti et al., 2009). Bakirci (2001) detected variable increases of AFM1 content in yogurt related to the milk. The effect of fermentation was assessed by Govaris et al. (2002) who reported that AFM1 levels in all yoghurt samples showed a significant decrease than those initially present in milk. This reduction in AFM1 was attributed to factors such as low $\mathrm{pH}$, formation of organic acids or other fermentation by products, or even to the presence of lactic acid bacteria. The contamination level of AFM1 in autumn and winter samples was significantly higher than those of spring and summer (Kamkar, 2005).

The European Union (Commission Regulation, EC, 2006) has established a lower maximum allowable level for AFM1 in milk of $50 \mathrm{ng} / \mathrm{l}$ and $250 \mathrm{ng} / \mathrm{kg}$ for cheese. Many other countries have followed the European Union standards (Dashti et al., 2009). In Egypt, the ministry of health established in 1990 that fluid milk and dairy products should be free from AFM1 and currently the maximum permissible levels follow the European Union standard (Egyptian Standard, 2007). AFM1 in dairy products is a serious health hazard for consumers specially children who are more sensitive to adverse effects of aflatoxin than adults (Fallah, 2010).

Amer and Ibrahim (2010) reported that a total number of 50 raw milk samples and 150 cheese samples (fifty of each soft cheese, hard cheese and processed cheese samples) were analyzed. They showed that the mean concentration values of AFM1 in soft and hard cheese samples were higher than that in raw milk samples. Processed cheese samples were the least contaminated samples. All positive samples of raw milk and cheeses are exceeding Egyptian regulations (free from AFM1) while all of them are within the US regulations (500 $\mathrm{ng} / \mathrm{l}$ or $\mathrm{Kg}$ ). All positive samples of cheese were exceeding the European Commission regulation (50 ng/l or $\mathrm{Kg}$ ), while $52.6 \%$ of examined raw milk samples were exceeding the European Commission regulation.

Motawee (2013) studied the elevated levels of AFM1 in milk and milk products. He found that conversion of milk into Domiati cheese and its subsequent storage period for 3 months produced an overall 64\% reduction of AFM1.

AFM1 could be detected in milk $12-24$ hr., after the first AFB1 ingestion, reaching a high level after a few days. The ration between $\mathrm{AFB}_{1}$ excreted has been estimated to be 1-3\% (Fallah, 2010). On the other hand, AFM1 is a very stable aflatoxin, so that it is not destroyed by storage or processing, such as pasteurization, autoclaving or other methods used in the production of fluid milk, and if present in raw milk it may persist into final products for human consumption (Tajkarimi et al., 2008).

Recently, El Kest et al. (2015) showed the serious risk for public health since all age groups, including infants and children, consume milk and its products worldwide. For this reason, milk and milk products have to be controlled continuously for presence of AFM1 contamination. It is also extremely important to maintain low levels of AFB1 in the feeds of dairy animals.

Bakirci (2001) reported that sterilization of milk at $121^{\circ} \mathrm{C}$ for $15 \mathrm{~min}$ caused $12.21 \%$ degradation of AFM1, whereas boiling decreased AFM1 by $14.50 \%$. They concluded that destruction of AFM1 depends on time and temperature combination of the heat treatment applied. Many authors showed that seasonal effect influences concentration of aflatoxin M1. They reported higher concentration of AFM1 in cold seasons as compared to hot seasons (Hussain and Anwar, 2008; Tajkarimi et al., 2008; Fallah, 2010, Bilandzic et al., 2010).

Many probiotic organisms have their origins in fermented foods, and their "'history of safe use" in human consumption allows the status of generally recognized as safe, some strains of lactic acid bacteria (LAB) have been shown to inhibit both growth of moulds and the production of mycotoxins (El-Shafei et al., 2010). 
Recently, El-Sayed (2015) investigated the effect of Lactobacillus lactis, Lactobacillus helviticus and their protein of metabolite in dexifing aflatoxins produced by Aspergillus flavus and Aspergillus prasiticus. A. flavus produced aflatoxins B1 and B2 with the amounts of 5548.12 and $389.20 \mathrm{Ug} / 1$, respectively. $A$. parasiticus produced aflatoxin B1 with amount $2970 \mathrm{Ug} / 1$. A. flavus was grown and interacted with either L. lactis or L. helviticus metabolite on $50 \mathrm{ml}$ of yeast extract socrous (YES) medium. Bacterial species used have ability to inhibite the aflatoxin production. Different concentrations from 0.1 to $0.6 \mathrm{~g} / \mathrm{ml}$ of antifungal pellet of L. lactis and L. helviticus which was precipitated by ammonium sulphate were tested with $A$. flavus and A. prasiticus. There was gradual inhibition of aflatoxins production of $A$. flavus from 0.1 to $0.3 \mathrm{~g} / \mathrm{ml}$ and greater inhibition for aflatoxin production at the higher concentrations from 0.4 to $0.6 \mathrm{~g} / \mathrm{ml}$, while with A. prasiticus aflatoxins were not detected at all concentrations from 0.1 to $0.6 \mathrm{~g} / \mathrm{ml}$.

The present study aimed to investigate the aflatoxin M1 contaminated in raw milk, kareish cheese and yoghurt, in addition, to study the ability of heating and probiotic bacteria to reduce the AFM1 contaminated of both raw milk and yoghurt.

\section{MATERIALS AND METHODS}

\section{Isolation and Purification of Moulds}

One tenth $\mathrm{ml}$ of each samples dilution was spread onto the surface of solidified Martin's medium (Baruah and Barthakur, 1997) and Yeast extract - glucose - chloramphenicol -blue - agar medium (YGCB- agar, Perkoppovà et al., 1984). Petri dishes were incubated at $30^{\circ} \mathrm{C} \pm 2$ for 5 days then counted. Single colonies of moulds were picked up, streaked on slants of YM agar test tubes, and kept at $4^{\circ} \mathrm{C}$ until used.

\section{Evaluation of Toxigenic Potential of Isolated Strains}

Two methods were used to assess the toxigenic potential: a medium- based qualitative system and high performance liquid chromatography (HPLC) analyses for quantification of aflatoxins production, as follows:

\section{Qualitative assay}

According to the method of (Dyer and McCammon, 1994)

\section{Quantitative analysis of aflatoxin}

Using the HPLC, according to the method of (Filtenborg and Frisvad 1980).

The HPLC system instrument used for aflatoxins determination was Perkin-Elmer, series 200 system (USA), equipped with quaternary pump, fluorescence detector and a C18 column chromatography Phenomenex (250 x $4.6 \mathrm{~mm}, 5 \mu \mathrm{m})$. The mobile phase was water: methanol: acetonitrile $(60: 30: 10)$ using as isocratic flow rate of $1.2 \mathrm{ml} \mathrm{min}-1$ at $360 \mathrm{~nm}$ excitation and 440nm emission wave length and a 30 min run time for aflatoxins.

\section{Effect of Heating on Aflatoxins}

\section{Milk samples inoculation}

Aflatoxin M1 negative milk samples (total volume about 10 liters) were mixed, divided into 4 main groups, and inoculated with 10, 5, 2.5 and $1.25 \mathrm{ng} / \mathrm{l}$ AFM1 standard, respectively.

\section{Treatment of the inoculated samples}

Each group subdivided into 3 subgroups of 4 milk samples (100 ml each). The $1^{\text {st }}$ subgroup let as control. The $2^{\text {nd }}$ subgroup subjected to pasteurization at $65^{\circ} \mathrm{C}$ for 30 minutes followed by sudden cooling at $4^{\circ} \mathrm{C}$. The $3^{\text {rd }}$ subgroup treated by boiling at about $100^{\circ} \mathrm{C}$ for 10 minutes (National Dairy Council, 1993).

\section{Detoxification of AFM1 in yoghurt by lactic acid bacteria}

\section{Cultures activation}

Lactic acid bacteria were obtained from ASU, Faculty of Agriculture, Cairo MIRCEN, (Egypt). The cultures were activated in $11 \%$ reconstituted skim milk for several times and the last 3 times were in specific medium at $37^{\circ} \mathrm{C}$ for all strains.

\section{Preparation of lactic acid bacteria (LAB) inoculum}

Lactobacilus acidophilus and Bifidobacterium lactis were originally obtained from ASU, Faculty of Agriculture, Cairo MIRCEN, (Egypt) and cultivated in $25 \mathrm{ml}$ De Man Regosa and 
Sharp medium (MRS) broth and Agar (Oxoid $\mathrm{CM} 359$ ) at $37^{\circ} \mathrm{C}$ for $24 \mathrm{hr}$. On the other hand, Bifidobacterium lactis cultivated in $25 \mathrm{ml}$ MRS broth (Oxoid 358) at $37^{\circ} \mathrm{C}$ for $24 \mathrm{hr}$. The suspensions were centrifuged at $1.700 \times \mathrm{g}$ for 15 minutes. The supernatants were discarded and the bacterial pellets were washed twice with phosphate buffered saline (PBS; pH 7.3, 0.01 $\mathrm{M})$. LAB and Bifidobacterium were adjusted to $3 \times 10^{8}$ and $7.6 \times 10^{6}$ bacteria per $4 \mathrm{ml}$ PBS (per tube), respectively.

\section{Binding ability of LAB in AFM1}

In order to study the binding ability of LAB, a combination of Lactobacillus acidophilus (2\%), Bifidobacterium lactis (2\%) was done. One melliter of a combination of Lactobacillus acidophilus (1\%) and Bifidobacterium lactis 1\% $(0.5 \mathrm{ml}$ each $)$ were suspended separately in a Falcon tube containing $49 \mathrm{ml}$ of naturally contaminated commercial UHT skim milk with AFM1 concentration of (25, 50 and 75) ppt and incubated at $37^{\circ} \mathrm{C}$ for $5 \mathrm{hr}$. Unbound AFM1 content was determined by HPLC analysis after 24, 48 and 72 hrs., during storage period at $4 \pm 1^{\circ} \mathrm{C}$. The toxin was measured using HPLC, cell- free milk contaminated with AFM used as a positive control. Bacteria suspended in noncontaminated skim milk were used as negative control (pure species) and all assays were performed in triplicate, Mohamed (1998).

\section{RESULTS AND DISCUSSION}

Mould contamination not only causes deterioration of food and feed, but also can adversely affect the health of humans. Moreover, fungi influence the biochemical characters and flavor of the product and often results in down grading of the product.

Table 1 shows the results of 72 samples of milk and dairy products (cheese and yoghurt) tested for moulds producing AFM1 contamination. It is clear that moulds producing AFM1 were found in $70.83 \%$ (17 out of 24 samples) of raw milk. Although, 91.67\% (22 out of 24 samples) of kareish cheese were positive, 12 out of 24 samples (50\%) of yoghurt were positive.

\section{Aflatoxin (AFM1) in Raw Milk}

Data presented in Table 2 show the occurrence of AFM1 in raw milk and its concentration (ng/l) in both summer and winter seasons. The AFM1 was detected in only 10 out of 12 samples in each season. In addition, winter season had higher AFM1 concentration than that of the summer season with the average values of 311.8 and $207.0 \mathrm{ng} / \mathrm{l}$, respectively.

These results were higher than that of the European Union (Commission Regulation, EC, 2006) which has established a lower maximum allowable level of AFM1 in milk (50 ng/l) and (250 ng/kg) for cheese. Many other countries have followed the European Union standards (Dashti et al., 2009). In Egypt, the ministry of health established in 1990 that fluid milk and dairy products should be free from AFM1 and currently the maximum permissible levels follow the European Union standard (Egyptian Standard, 2007). So, for any country (including Egypt), any increase in the proportion of AFM1 in milk and dairy products, above the permissible limit of Codex can affect international trade of such milk products in global markets.

The present results show that the AFM1 concentrations in milk samples were higher in the winter season than that in summer season which is in agreement with the results of Tajkarimi et al. (2008) who reported that AFM1 concentrations in milk samples in winter were significantly higher than that of summer $(\mathrm{P}<0.05), 30 \%$ of samples in winter were $>50$ ng.l-1; however, in summer $16 \%$ of samples were $>50 \mathrm{ng}$. $1-1$. One reason for this is that milking animals are fed with compound feeds in winter that are prone to aflatoxin B1 concentration (Kamkar, 2005; Hussain and Anwar, 2008).

\section{Aflatoxin (AFM1) in Kareish Cheese}

Data presented in Table 3 show the occurrence of Aflatoxin M1 in kareish cheese and its concentration $(\mathrm{ng} / \mathrm{kg})$ in both summer and winter seasons. The AFM1 was detected in all samples (24) in both summer and winter seasons. In addition, the international legistion on AFM1in milk and dairy products for human consumption is given in Table 5. Also, the highest values of AFM1 were 1295.0 and 1612.0 (ng/Kg), whereas the lowest values were 32.56 and 36.57 (ng/Kg) in summer and winter seasons, respectively. It was clear that AFM1 concentration in summer was lower than that of winter season with average values of 527.4 and 651.36 (ng/Kg), respectively. 
Table 1. Incidence of moulds producing AFM1 in milk and dairy product samples

\begin{tabular}{|c|c|c|c|c|c|}
\hline \multirow{3}{*}{$\begin{array}{c}\text { Examined } \\
\text { samples }\end{array}$} & \multirow{3}{*}{$\begin{array}{l}\text { Total No. of } \\
\text { examined } \\
\text { samples }\end{array}$} & \multicolumn{4}{|c|}{ Moulds } \\
\hline & & \multicolumn{2}{|c|}{ Positive } & \multicolumn{2}{|c|}{ Negative } \\
\hline & & No. & $(\%)$ & No. & $(\%)$ \\
\hline Raw milk & 24 & 17 & 70.83 & 7 & 29.17 \\
\hline Kareish cheese & 24 & 22 & 91.67 & 2 & 8.33 \\
\hline Yoghurt & 24 & 12 & 50.00 & 12 & 50.00 \\
\hline
\end{tabular}

Table 2. Occurrence of Aflatoxin M1 in raw milk and its concentration (ng/l) in summer and winter seasons

\begin{tabular}{ccccc}
\hline $\begin{array}{c}\text { Summer } \\
\text { season }\end{array}$ & Samples & AFM1 (ng/l) & Winter season & AFM1 (ng/l) \\
\hline June 2013 & A(M) & 9.80 & December 2013 & 000.00 \\
& B(M) & 86.2 & & 100.90 \\
& C(M) & 538.0 & & 520.43 \\
July 2013 & D(M) & 422.0 & & 386.31 \\
& A(M) & 0.00 & January 2014 & 78.600 \\
& B(M) & 66.73 & & 246.05 \\
August & C(M) & 423.01 & & 577.80 \\
2013 & D(M) & 309.4 & & 392.40 \\
& A(M) & 0.00 & February 2014 & 00.000 \\
& B(M) & 8.30 & & 274.02 \\
Mean & C(M) & 339.5 & & 698.30 \\
& D(M) & 291.1 & & 467.12 \\
& & 207 & & 311.8 \\
\hline
\end{tabular}


Table 3. Occurrence of Aflatoxin M1 in kareish cheese and its concentration (ng/kg) in summer and winter seasons

\begin{tabular}{ccccc}
\hline $\begin{array}{c}\text { Summer } \\
\text { season }\end{array}$ & Samples Positive & AFM1 (ng/kg) & Winter season & AFM1 (ng/kg) \\
\hline June 2013 & A(Ch) & 487.20 & December 2013 & 36.570 \\
& B(Ch) & 591.30 & & 239.15 \\
& C(Ch) & 1295.0 & & 588.00 \\
& D(Ch) & 762.45 & & 467.04 \\
July 2013 & A(Ch) & 46.11 & January 2014 & 184.36 \\
& B(Ch) & 392.25 & & 326.35 \\
& C(Ch) & 856.09 & & 1612.0 \\
August 2013 & D(Ch) & 458.00 & & 755.09 \\
& A(Ch) & 32.56 & February 2014 & 227.64 \\
& B(Ch) & 388.50 & & 479.40 \\
& C(Ch) & 566.70 & & 1535.0 \\
Mean & D(Ch) & 453.65 & & 1365.7 \\
\hline
\end{tabular}

The European Union (Commission Regulation, EC, 2006) has established a lower maximum allowable level for AFM1 in milk of $50 \mathrm{ng} / \mathrm{l}$ and $250 \mathrm{ng} / \mathrm{kg}$ for cheese (Table 5). Many other countries had followed the European Union standards (Dashti et al., 2009). So, for any country (including Egypt) any increase in the proportion of AFM1 in milk and dairy products above the permissible limit of Codex and other countries can affect international trade of such milk products in global markets.

In the current studies results show that 83.33\% of kareish cheese samples (20 out of 24) examined exceeded the limits of EU (50 ng/kg) and $70.83 \%$ of cheese samples examined (17 out of samples) exceeded the limits of codex (500 ng/kg) in both summer and winter seasons. In Egypt, the ministry of health established in 1990 that fluid milk and dairy products should be AFM1 free and currently the maximum permissible levels follow the European Union standard (Egyptian Standard, 2007).

Amer and Ibrahim (2010) reported that a total number of 50 raw milk samples and 150 cheese samples (fifty of each soft cheese, hard cheese and processed cheese samples) were analysed. They showed that the mean concentration values of AFM1 in soft and hard cheese samples were higher than that in raw milk samples. Processed cheese samples were the least contaminated samples. All positive samples of raw milk and cheeses are exceeding Egyptian regulations (free from AFM1) while all of them are within the US regulations (500 $\mathrm{ng} / \mathrm{l}$ or $\mathrm{Kg}$ ). All positive samples of cheese were exceeding the European Commission regulation (50 ng/l or $\mathrm{Kg}$ ), while $52.6 \%$ of examined raw milk samples were exceeding the European Commission regulation. Another study in Egypt exhibited that, the range of AFM1 in Kareish cheese samples was 5000 to 35000 ppt with mean value 17500 ppt (El-Diasty and Salem, 2008). Also, soft cheese (fresh Karish and Domiati) samples were examined and found that the mean values were 3600 and 67000 ppt. (Awad et al., 2014), While no detection for aflatoxin in some cheese samples were reported by others (Sessou et al., 2013; Fontaine et al., 2015). 


\section{Aflatoxin (AFM1) in Yoghurt}

Data presented in Table 4 show the occurrence of Aflatoxin M1 in yoghurt and its concentration $(\mathrm{ng} / \mathrm{kg})$ in both summer and winter seasons. In summer season, the highest value of AFM1 concentration was $66.05 \mathrm{ng} / \mathrm{kg}$ while the lowest value of AFM1 concentration was $31.46 \mathrm{ng} / \mathrm{kg}$., the AFM1 did not detect in 3 out of 12 samples. In winter, the highest value of AFM1 concentration was $84.14 \mathrm{ng} / \mathrm{kg}$ while the lowest value of AFM1 concentration was 56.60 $\mathrm{ng} / \mathrm{kg}$., the AFM1 did not detect in 1 out of 12 samples collected (Table 4).

With respect to yoghurt, several surveys were performed in order to determine the AFM1 levels in yoghurt. About $80 \%$ of all yoghurt samples in Italy were contaminated with AFM1, which ranged between 1- $3.1 \mathrm{ng} / \mathrm{kg}$ (Galvano et al., 1998). Later, $61.0 \%$ yoghurt samples were contaminated with AFM1 at lower levels than those in previous survey (Galvano et al., 2001). In Portugal, 48 samples of yoghurt were tested and only $2(4.2 \%)$ were contaminated with AFM1 at level of $0.45 \mathrm{ng} / \mathrm{kg}$ (Martins and Martins, 2004). However, in Brazil; there was no detection for AFM1 in 30 of tested yoghurt samples (Kaniou-Grigoriadou et al., 2005). However, most of the yoghurt samples (62.88\%) purchased at different markets in Ankara were free of AFM1 (Sarimehmetoglu et al., 2004). Also in Turkey, it was revealed that $65.38 \%$ of ordinary yoghurt samples, $33.33 \%$ of fruit yoghurt samples, and $55.77 \%$ of strained yoghurt samples contained the aflatoxin (Akkaya et al., 2006). AFM1 occurrence in $2.8 \%$ of yoghurt samples was determined (CanoSancho et al., 2010). According to observations, the levels of contamination of local yoghurt by AFM1 seem to vary in many studies. These variations may be related to different reasons such as yoghurt manufacturing procedures, different milk contaminations, type of yoghurt, conditions of yoghurt ripening, geographical region, the country, the season and the analytical methods employed (Van Egmond et al., 2007; Di Guan et al., 2011).

In contrast, (Bakirci, 2001) detected variable increases of AFM1 content in yoghurt related to the milk. The effect of fermentation was assessed by (Govaris et al., 2002).They reported that AFM1 levels in all yoghurt samples showed a significant decrease from those initially present in milk. This decrease in AFM1 was attributed to factors such as low $\mathrm{pH}$, formation of organic acids or other fermentation byproducts, or even to the presence of lactic acid bacteria. The low $\mathrm{pH}$ during fermentation alters the structure of milk proteins such as the caseins leading to formation of yoghurt coagulum.

\section{Aflatoxin Control}

Two treatments were applied to reduce the concentration of AFM1in raw milk and milk product (yoghurt), which include heating (boiling and pasteurization) and probiotic bacteria.

\section{Effect of heating}

Table 6 show the mean concentration (ppt) and detoxification (\%) of AFM1 in different treated milk samples. It is clear that application of heating reduced the concentrations of AFM1 in all raw milk samples. The application of pasteurization reduced the AFM1 concentrations in raw milk by average of $15.45 \%$ which ranged from 10.0 to $22.6 \%$, where, application of boiling amounted an average of AFM1 reduction of $26.7 \%$ which ranged from 25.47 to $28.57 \%$. The present results concluded that boiling caused $26.71 \%$ degradation of AFM1 whereas pasteurization caused only $15.45 \%$ degradation.

The present results are in good agreement with the results reported by Choudhary et al. (1998) who reported that sterilization of milk at $121^{\circ} \mathrm{C}$ for 15 min caused $12.21 \%$ degradation of AFM1, whereas boiling decreased AFM1 by $14.50 \%$. Additionally, pasteurization plays a role in the aflatoxin reduction as reported by Bakirci (2001), who reported that pasteurization caused a decrease in the level of AFM1 at the rate of $7.62 \%$. Also, Deveci (2007) showed that pasteurization can partially reduce the amount of AFM1 in milk. Furthermore, Hossein et al. 2007) recorded AFM1 level of 8.7 ppt in pasteurized milk samples which was $24.2 \mathrm{ppb}$ in raw milk samples collected from the same area.

However, ultra high temperature (UHT) milk contamination levels were lower than those in raw milk. In fact, due to idea that heating or storing at lower temperatures would not cause an appreciable change in the amount of AFM1 (Prandini et al., 2009). Many authors showed that seasonal effect influences concentration of aflatoxin M1. 
Table 4. Occurrence of Aflatoxin M1 in yoghurt and its concentration (ng/kg) in summer and winter seasons

\begin{tabular}{|c|c|c|c|c|}
\hline $\begin{array}{l}\text { Summer } \\
\text { season }\end{array}$ & $\begin{array}{l}\text { Samples } \\
\text { Positive }\end{array}$ & $\begin{array}{l}\text { AFM1 } \\
\text { (ng/kg) }\end{array}$ & $\begin{array}{l}\text { Winter } \\
\text { season }\end{array}$ & $\begin{array}{l}\text { AFM1 } \\
\text { (ng/kg) }\end{array}$ \\
\hline \multirow[t]{4}{*}{ June 2013} & $\overline{A(Y)}$ & 00.00 & December 2013 & 000.00 \\
\hline & $\mathbf{B}(\mathbf{Y})$ & 55.07 & & 56.60 \\
\hline & $\mathrm{C}(\mathrm{Y})$ & 66.05 & & 77.13 \\
\hline & $\mathbf{D}(\mathbf{Y})$ & 56.89 & & 65.50 \\
\hline \multirow[t]{4}{*}{ July 2013} & $\mathbf{A}(\mathbf{Y})$ & 00.00 & January 2014 & 62.96 \\
\hline & $\mathbf{B}(\mathbf{Y})$ & 46.23 & & 59.84 \\
\hline & $C(Y)$ & 62.06 & & 84.14 \\
\hline & $\mathrm{D}(\mathrm{Y})$ & 58.33 & & 74.08 \\
\hline \multirow[t]{4}{*}{ August 2013} & $A(Y)$ & 00.00 & February 2014 & 60.72 \\
\hline & $\mathbf{B}(\mathbf{Y})$ & 31.46 & & 75.39 \\
\hline & $C(Y)$ & 51.66 & & 82.90 \\
\hline & $\mathrm{D}(\mathrm{Y})$ & 41.85 & & 79.85 \\
\hline Mean & & 39.13 & & 64.68 \\
\hline
\end{tabular}

Table 5. International legislation on AFM1 in milk and dairy products for human consumption. El Khoury et al. (2011)

\begin{tabular}{lll}
\hline Country & Raw milk $(\boldsymbol{\mu g} / \mathbf{k g})$ & Dairy products $(\boldsymbol{\mu g} / \mathbf{k g})$ \\
\hline Argentina & 0.05 & 0.50 (milk products) \\
Australia & $0.05,0.01$ (pasteurized infant milk) & 0.02 (butter), 0.25 (cheese), 0.4(powdered milk) \\
Egypt & 0 & 0 \\
European Union & 0.05 & 0.05 \\
Honduras & 0.05 & 0.25 (cheese) \\
Rumania & 0 & 0 \\
Switzerland & 0.05 & 0.025 (milk whey and products), 0.25 (cheese), \\
Turkey & 0.05 & 0.02 (butter) \\
USA & & 0.25 (cheese) \\
\hline
\end{tabular}


Table 6. The mean concentration (ppt) and detoxification (\%) of AFM1 in different treated milk samples

\begin{tabular}{|c|c|c|c|c|c|}
\hline \multirow{2}{*}{$\begin{array}{c}\text { Initial AFM1 } \\
\text { levels (ppt) }\end{array}$} & \multirow{2}{*}{$\begin{array}{c}\text { Positive } \\
\text { control levels } \\
\text { (ppt) }\end{array}$} & \multicolumn{2}{|c|}{ Pasteurization treatments } & \multicolumn{2}{|c|}{ Boiling treatments } \\
\hline & & $\begin{array}{c}\text { Concentration } \\
\text { (ppt) }\end{array}$ & $\begin{array}{c}\text { Detoxification } \\
(\%)\end{array}$ & $\begin{array}{c}\text { Concentration } \\
\text { (ppt) }\end{array}$ & $\begin{array}{c}\text { Detoxification } \\
(\%)\end{array}$ \\
\hline Group I (10) & 9.4 & 8.00 & 14.9 & 6.90 & 26.60 \\
\hline Group II (5.00) & 4.2 & 3.60 & 14.3 & 3.10 & 26.19 \\
\hline Group III (2.50) & 2.1 & 1.89 & 10.0 & 1.50 & 28.57 \\
\hline Group IV (1.25) & 1.06 & 0.82 & 22.6 & 0.79 & 25.47 \\
\hline Average & 4.19 & 3.58 & 15.45 & 3.07 & 26.71 \\
\hline
\end{tabular}

They reported higher concentration of AFM1 in cold seasons as compared to hot seasons (Hussain and Anwar, 2008; Tajkarimi et al., 2008; Fallah, 2010; Bilandzic et al., 2010). Thus, exposure milk to boiling may be precious to reduce the levels of AFM1 and subsequently diminish its perilous on the public health.

\section{Effect of probiotic bacteria}

Various species of genera Lactobacillus and Bifidobacterium mainly have been used as probiotics over the years (Shahin, 2007; Ranadheera et al., 2010).

Table 7 show that the two strains of (LAB), Lacotobacillus acidophilus and Bifidobacterium lactis were tested for aflatoxin M1 reduction in contaminated milk with 25.0 ppt AFM1. It is clear that there was a gradual reduction as a function of time with complete elimination by the end of storage period (3 days) at refrigerator, where Lactobacillus acidophilus and Bifidobacterium lactis showed more ability for removing of AFM1. After one day, the concentration of AFM1 decreased to $17.8 \mathrm{ppt}$ (28.8\%), 10.4 ppt (58.4\%) and 5.6ppt (77.6\%) in the presence of $L$. acidophilus (2\%), B. lactis (2\%) and combination of L. acidophilus (1\%) and $B$. lactis (1\%), respectively. Meanwhile the most extensive reduction of AFM1 concentration of $8.6 \mathrm{ppt}$ (65.6\%), $6.9 \mathrm{ppt}$ (72.4\%) and 1.2 ppt (95.2\%) was achieved by using the same concentrations of lactic acid bacteria after $48 \mathrm{hr}$. No aflatoxin M1 was detected in the third day.

Data show also, that the two strains of (LAB), Lacobacillus acidophilus and Bifidobacterium lactis were tested for aflatoxin M1 reduction in contaminated milk with (50.0 ppt) AFM1 respectively. After one day, the concentration of aflatoxin M1 decreased to (37.5 ppt (25.0\%), 24.4 ppt (51.2\%) and 17.3 ppt (75.4\%) in the presence of $L$. acidophilus (2\%), B. lactis (2\%) and combination of L. acidophilus (1\%) and B. lactis (1\%), respectively. Meanwhile the most extensive reduction of AFM1 concentration of (13.6 ppt (72.8 \%), 5.9 ppt (88.2\%) and 2.6 ppt (94.4\%) was achieved by using the same concentrations of lactic acid bacteria after $48 \mathrm{hr}$. No aflatoxin M1 was detected in the third day.

On the other hand, Data show also, that the two strains of (LAB), L. acidophilus and B. lactis were tested for aflatoxin M1 reduction in contaminated milk with (75 ppt) AFM1. After one day reduction of AFM1 concentration to 62.7 ppt (16.4\%), 51.5 ppt (31.3\%) and 32.8 ppt (56.3\%), respectively. Meanwhile the most extensive reduction of AFM1 concentration of (41.8 ppt (45.3\%), 22.6 ppt (69.9\%) and 7.12 ppt $(92.8 \%)$ was achieved by using the same concentrations of lactic acid bacteria after $48 \mathrm{hr}$. No aflatoxin M1 was detected in combination of L. acidophilus (1\%) and B. lactis (1\%) in the third day. But, reduction of AFM1 concentration of L. acidophilus was 28.2 ppt (62.4\%) and B. lactis 3.90 ppt (94.8\%).

Concerning the effect of lactic acid bacteria on reducing the concentration of AFM1, the obtained results came in agreement with the results reported by (Mohamed, 1998), who measured a reduction of aflatoxin M1 in yoghurt made by L. acidophilus and Bifidobacterium 
Table 7. Reduction of Aflatoxin M1 (25, 50 and 75 ppt) in milk using Lactobacillus acidophilus (LA) and Bifidobacterium lactis (BL)

\begin{tabular}{|c|c|c|c|c|c|c|c|c|c|}
\hline \multirow{2}{*}{$\begin{array}{c}\text { Treatment } \\
\text { Days }\end{array}$} & \multirow[t]{2}{*}{$\begin{array}{c}\text { AFM1 } \\
\text { (ppt) }\end{array}$} & \multicolumn{2}{|c|}{ Control } & \multicolumn{2}{|c|}{$\begin{array}{l}\text { Lactobacillus } \\
\text { acidophilus }\end{array}$} & \multicolumn{2}{|c|}{$\begin{array}{c}\text { Bifidobacterium } \\
\text { lactis }\end{array}$} & \multicolumn{2}{|c|}{$(\mathbf{L A})+(\mathrm{BL})$} \\
\hline & & $\begin{array}{l}\text { Reduction } \\
\text { of AFM1 }\end{array}$ & $(\%)$ & $\begin{array}{c}\text { Reduction } \\
\text { of AFM1 }\end{array}$ & $(\%)$ & $\begin{array}{c}\text { Reduction } \\
\text { of AFM1 }\end{array}$ & $\overline{(\%)}$ & $\begin{array}{c}\text { Reduction } \\
\text { of AFM1 }\end{array}$ & $(\%)$ \\
\hline 1 day & 25 & 22.7 & 9.2 & 17.8 & 28.8 & 10.4 & 58.4 & 5.6 & 77.6 \\
\hline 2 day & 25 & 12.2 & 51.2 & 8.6 & 65.6 & 6.9 & 72.4 & 1.2 & 95.2 \\
\hline 3 day & 25 & 7.8 & 68.8 & ND & 100 & ND & 100 & ND & 100 \\
\hline 1 day & 50 & 48.9 & 2.2 & 37.5 & 25.0 & 24.4 & 51.2 & 17.3 & 65.4 \\
\hline 2 day & 50 & 44.3 & 11.4 & 13.6 & 72.8 & 5.9 & 88.2 & 2.6 & 94.4 \\
\hline 3 day & 50 & 39.8 & 20.4 & ND & 100 & ND & 100 & ND & 100 \\
\hline 1 day & 75 & 72.4 & 3.5 & 62.7 & 16.4 & 51.5 & 31.3 & 32.8 & 56.3 \\
\hline 2 day & 75 & 70.1 & 6.5 & 41.8 & 45.3 & 22.6 & 69.9 & 7.12 & 92.8 \\
\hline 3 day & 75 & 68.6 & 8.5 & 28.2 & 62.4 & 3.90 & 94.8 & ND & 100 \\
\hline
\end{tabular}

ND : Not Detected

bifidum of 95.3 and $84.7 \%$ of AFM1 after 5 days, respectively. Also, the same conclusion was reached when different spp. of lactic acid bacteria were used, the reduction level by these strains ranged from 26.2- 34.0\%, depending upon the bacterial isolates (Emara et al., 2000). As regards AFM1 stability during cold, ElKhoury et al. (2011) found that LAB ( $L$. bulgaricus and $S$. thermophiles strains) used in Lebanese dairy industries were effective in reducing the levels of AFM1 in liquid culture medium and during yoghurt processing. Therefore, LAB seems to play a crucial role in AFM1 removal and could be used as a biological agent for AFM1 reduction. From the obtained results it could be concluded that the all $\mathrm{LAB}$ and bifidobacteria under investigation have the ability to bind AFM1.

\section{REFERENCES}

Akkaya, L., Y.O. Birdane, H. Oguz and M. Cemek (2006). Occurrence of aflatoxin M1 in yogurt samples from afyonkarahisar, Turkey. Bull. Vet. Ins. Pulawy, 50: 517-519.
Amer, A.A. and M.A.E. Ibrahim (2010). Determination of Aflatoxin M1 in raw milk and traditional cheeses retailed in Egyptian markets. J. Toxicol. and Env. Health Sci., 2 (4): 50-53.

Awad, E., I. Marwa, A. Ibrahim and M.I. ElShaer (2014). Influence of probiotic on microbiological quality of kariesh cheese. Life Sci. J., 11 : 1 - 13.

Bakirci, I. (2001). A study on the occurrence of aflatoxin M1 in milk and milk products produced in Van province of Turkey. Food Control, 12: 45-51.

Baruah, T.C. and H.P. Barthakur (1997). A Test Book of Soil Analysis. Vikas publishing House PVTLTD.

Bilandzic, N., I. Varenina and B. Solomun (2010). Aflatoxin M1 in raw milk in Croatia. Food Control, 21: 1279-1281.

Cano-Sancho, G., S. Marin, A.J. Ramos, J. Peris-Vicente and V. Sanchis (2010). Occurrence of aflatoxin M1 and exposure 
assessment in Catalonia (Spain). Revista Iberoamericana de Micologia, 3:130-135.

Choudhary, P.L., R.S. Sharma, and V.N. Borkartria (1998). Effect of chilling and heating on aflatoxin M1 content of contaminated Indian cow's milk. Egyptian J. Dairy Sci., 26 : 223-229.

Codex Alimentarius Commissions (2001). Comments submitted on the draft maximum level for Aflatoxin M1 in milk. Codex committee on food additives and contaminants $33^{\text {rd }}$ sessions, Hauge, The Netherlands.

Commission Regulation (EC). (2006). Setting maximum levels for certain Contaminations in foodstuffs. Off. J. European Union L., 364 (1881): 5-24.

Dashti, B.S., A.H. Alomirah, S. Al-Zenki, A. Bu Abbas and W. Sawaya (2009). Levels of aflatoxin M1 in milk, cheese consumed in Kuwait and occurrence of total aflatoxin in local and imported animal feed. Food Control, 20 : 686-690.

Deveci, O. (2007). Changes in the concentration of aflatoxin M1 during manufacture and storage of White Pickled cheese. Food Control, 9 : 1103-1107.

Di Guan, PL., Q. Zhang, Z. Wen, Z. Daohong and J. Jun (2011). An ultra-sensitive monoclonal antibody-based competitive enzyme Immunoassay for aflatoxin M1 in milk and infant milk products. Food Chem., 125: 1359-1364.

Dyer, S.K. and S. McCammon (1994). Detection of aflatoxigenic isolates of Aspergillus flavus and related species on coconut cream agar. J. Appl. Bacteriol., 76 : 75-78.

Egyptian Standard (2007). Maximum levels of mycotoxin for foods and feeds, part-1: Aflatoxins. Egyptian Organization for Standardization and Quality, 1- 1875.

El Khoury, A., A. Atoui and J. Yaghi (2011). Analysis of aflatoxin M1 in milk and yogurt and AFM1 reduction by lactic acid bacteria used in Lebanese industry. Food Control, 22: 1695-1699.
El-Diasty, E.M. and R.M. Salem (2008). Incidence of lipolytic and proteolytic fungi in some milk products and their public health significance. Fac. Vet. Med., Omar ElMokhtar Univ., Libya, Food Control, (19) 6: 570-577.

El Kest, M.M., M. El-Hariri, N.I.M. Khafaga and M.K. Refai (2015) Studies on contamination of dairy products by aflatoxin M1 and its control by probiotics. J. Global Biosci., 4 (1): 1294-1312.

El-Sayed, T.I.(2015). Detoxification of aflatoxin by amino acids from metabolites of Lactobacillus lactis and Lactobacillus helviticus. Egyptian J. Dairy Sci, 6: 113-122.

El-Shafei, G.M.S., M.M. El- Said, H.A.E. Attia and T.G.M. Mohammed (2010). Environmentally friendly pesticides: essential oil-bases w/o/w/ multiple emulsions for antifungal formulations. Ind. Crop Prod., 31: 99106.

Emara, H., G. Bean and M. Trucksess (2000). Detoxification of aflatoxin M1 on lactic acid bacteria in contaminated with it milk. J. Agric. Sci. Mansoura Univ. Egypt, 25 (2): 945 - 953.

Fallah, A. (2010). Aflatoxin M1 contamination in dairy products marketed in Iran during winter and summer. Food Control, 21: 14781481.

Filtenborg, O. and J.C. Frisvad (1980). A simple screening method for toxigenic moulds in pure cultures. Lebensm Wiss Technol., 13 : 128-130.

Fontaine, K., E. Passeró, L. Vallone, N. Hymery, M. Coton, J. Jany, J. Mounier and E.E. Coton (2015). Occurrence of roquefortine $\mathrm{C}$, mycohenolic acid and aflatoxin M1 mycotoxins in blue-veined cheeses. Food Control, 47: 634-640.

Galvano, F., V. Galofaro, A. DeAngelis, M. Galvano, M. Bognanno and G. Galvano (1998). Survey of the occurrence of aflatoxin M1 in dairy products marketed in Italy. J. Food Prot., 61: 738-741.

Galvano, F., V. Galofaro, R. Ritieni, M. Bognanno, A. De Angelis and G. Galvano, 
(2001). Survey of the occurrence of aflatoxin M1 in dairy products marketed in Italy: second year of observation. Food Addiv. and Contaminants, 7 : 644-646.

Govaris, A., V. Roussi, P.A. Koudis and N.A. Botsoglou (2002). Distribution and stability of aflatoxin M1 during production and storage of yoghurt. Food Additives and Contaminants, 11: 1043-1050.

Hossein, T., M.R.R. Seyed and M. Mehran, (2007). Detection of aflatoxin $\mathrm{m} 1$ in raw and commercial pasteurized milk in Urmia, Iran. Pak. J. Biol. Sci., 10: 4103-4107.

Hussain, I. and J. Anwar (2008). A study on contamination of aflatoxin M1 in raw milk in the Punjab province of Pakistan. Food Control, 19 : 393-395.

Ito, Y., S.W. Peterson, D.T. Wicklaw and T. Goto (2001). Aspergillus pseudotamarii, a new aflatoxin producing sp. Mycol. Res., 105: 233-239.

Kamkar, A. (2005). A study on the occurrence of commission aflatoxin M1 in raw milk produced in Sarab city of Iran. Food Control, 16: 593-599

Kaniou-Grigoriadou, I., A. Eleftheriadou, T. Mouratidou and P. Katikou (2005). Determination of aflatoxin M1 in ewe's milk samples and the produced curd and Feta cheese. Food Control, 16: 257-261.

Martins, M.L. and H.M. Martins (2004). Aflatoxin M1 in raw and ultra high temperature-treated milk commercialized in Portugal. Food Additives and Contaminants, 17 (10) : 871-874.

Mohamed, O.A. (1998): Stability of AFM1 and AFB1 in yoghurt manufactured by Lactobacills acidophilus and Bifidobacterium bifidum. AlAzhar J. Agric. Res., 27: 104-120.

Motawee, M.M., J. Bauer and D.J. McMahon (2009). Survey of Aflatoxin M1 in cow, goat, buffalo and camel milks in Ismailia, Egypt. Bulletin of Environ. Contamination and Toxicol., 83 (5) 766-769.

Motawee, M.M. (2013). Reduction of Aflatoxin M1 Content during Manufacture and Storage of Egyptian Domaiti Cheese. Int. J. Vet. Med. Article ID 207299, 10.

National Dairy Council (1993). Newer Knowledge of Milk and Other Fluid Dairy Products. The Council, Rosemont, IL. Dairy Foods CDE 60018.

Perkoppovà, C.R.J., A.C.G. Oliveira, M.H.F. Spoto, S.G. Canniatti-Brazaca and C.P. Sousa (1984). Comparison of nutrient media for determination of yeasts and moulds in cheese. Bulletin. Potervinarskeka, 23(24): 537-561.

Prandini, A., G. Tansini, S. Sigolo, L. Filippi, M. Laporta and G. Piva (2009). Review: on the occurrence of aflatoxin M1 in milk and dairy products. Food and Chem. Toxicol., 47 984-991.

Ranadheera R.D.C.S., S.K. Baines and M.C. Adams (2010). Importance of food in probiotic efficacy. Food Res. Int., 43:1-7.

Sarimehmetoglu, B., O. Kuplulu and T.H. Celik (2004). Detection of aflatoxin M1 in cheese samples by ELISA. Food Control, 15: 45-49.

Sessou, P., S. Farougou, F. Tchobo, P. Agbangnan, E. Adjalian, P. Azokpota and I. Youssao (2013). In vitro evaluation of aflatoxin M1 control potential of six essential oils in benin. IJCRR., 5(8): 11-19.

Shahin, A.A.M. (2007). Removal of aflatoxin B1 from contaminated liquid media by dairy lactic acid bacteria. Int. J. Agric. Biol., 9: 71-75.

Tajkarimi, M., F. Aliabadi-Sh, A. Salah Nejad, H.H. Poursoltani, A.A. Motallebi and H. Mahdavi (2008). Aflatoxin M1contamination in winter and summer milk in 14 states in Iran. Food Control, 19:1033-1036.

Van Egmond, H.P and S. Dragacci (2001). Liquid Chromatography Method for Aflatoxin M1 in milk in method of molecularbio. Vol. mycotoxin USA., 157 : 59-69.

Van Egmond, H.P., R.C. Schothorst and M.A. Jonker (2007). Regulations relating to mycotoxins in food: Perspectives in a global and European context, Anal Bioanal Chem., 389: $147-157$. 


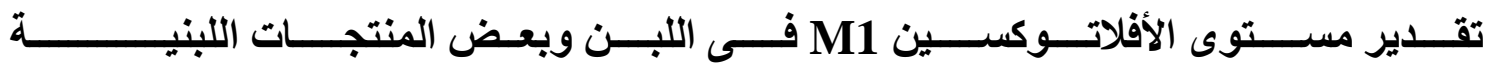

دعاء خضرى إبراهيم- فاطمة إبراهيم إلزامك- جمال الدين مصطفى محمد-هويدا محمد لبيب عبد الباسط قسم الميكروبيولوجيا الزراعية_كلية الزر اعة- جامعة الزقازيقـ الرقم البريدى(

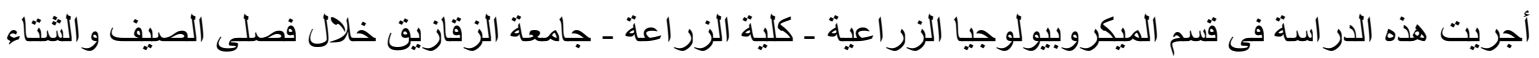

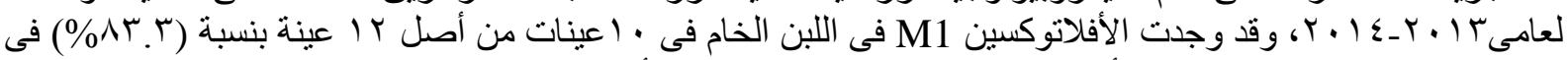

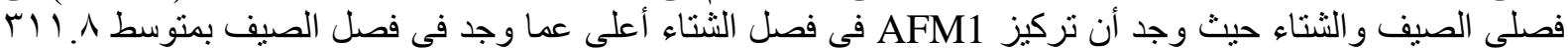

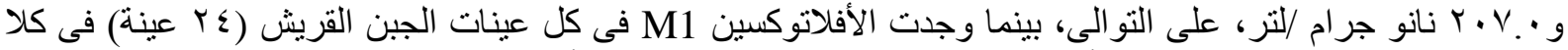

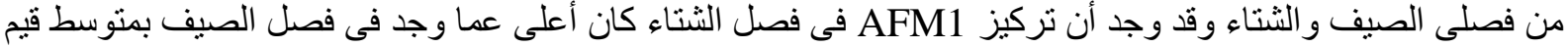

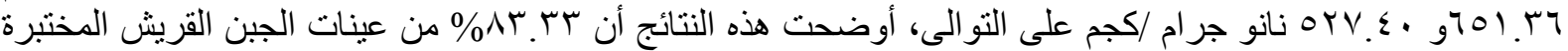

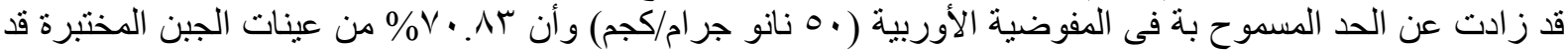

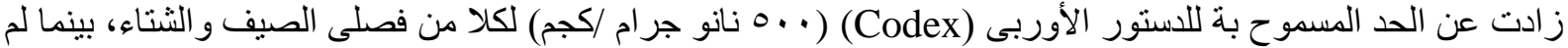

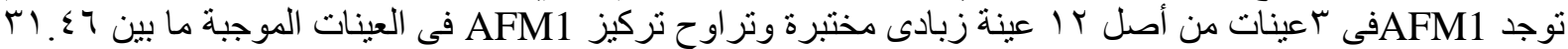

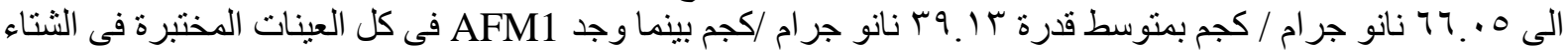

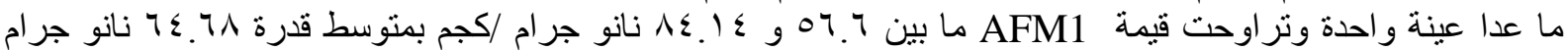

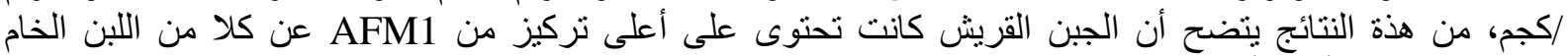

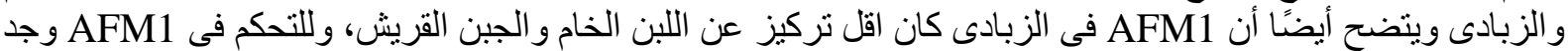

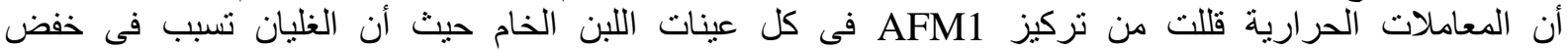

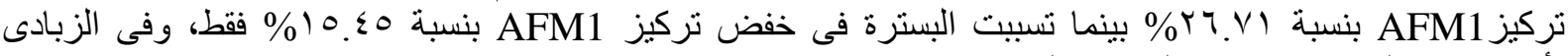
بأستخدام سلالتنين من بكتيريا البروبيوتيك (Lactobacillus acidophilus , Bifidobacterium lactis) كلا بمفردة فئن

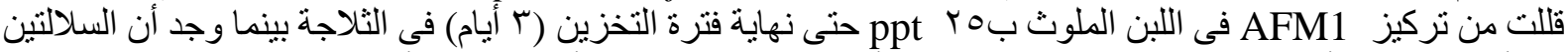

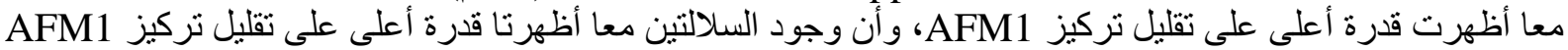

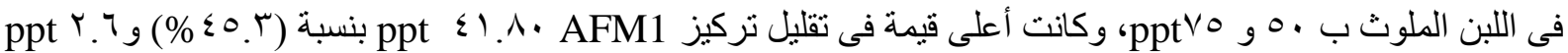

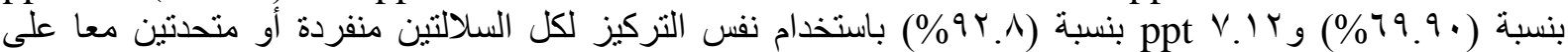

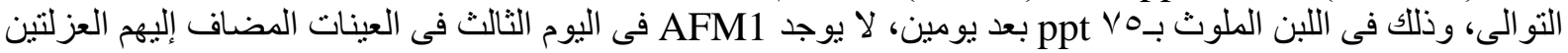

